\title{
Improved staining of leprosy bacilli in tissues
}

\author{
K HARADA \& K SUZUKI \\ Laboratory, National Tamazenseiyen Sanatorium, Higashimur- \\ ayama, Tokyo, 189, Japan
}

Accepted for publication 3 February 1989

Summary A technique which reliably demonstrates Mycobacterium leprae, $M$. tuberculosis and fungi in tissues is described. It is based on the oxidation of cell wall lipid substances by chromic or periodic acid, and the subsequent release of aldehydes which are then capable of reducing ammoniacal silver salt solutions to metallic silver. The organisms so demonstrated appear uniformly solid. The sensitivity of the method and the ease of examination and recognition of bacilli and their products are recommendations for the use of the method in diagnosis and research, disregarding morphological appearances.

\section{Introduction}

For unknown reasons it is often difficult to demonstrate Mycobacterium leprae in tissues. This is especially so with material which has been fixed for long periods in formalin, or when organisms are in an advanced state of decay, or if they are not acid-f ast by the conventional Ziehl-Neelsen staining method. Greater sensitivity of staining can be achieved using prior oxidation with periodic acid and subsequent staining in carbolfuchsin, ${ }^{1,2}$ or carbol-pararosanilin. ${ }^{3,4}$ Silver impregnation, originally used to demonstrate fungi in tissues ${ }^{5}$ is another reliable means of staining mycobacteria. ${ }^{6-8}$ Harada $^{9,10}$ made use of prior oxidation followed by silver impregnation to enhance the demonstration of mycobacteria in tissues.

The method described below is based on the same principle. Leprosy bacilli, tubercle bacilli, other mycobacteria and certain fungi can be clearly visualized by this technique.

\section{Materials and methods}

\section{TISSUES}

Human skin lesions of various forms of leprosy, pulmonary lesions of tuberculosis and fungal lesions were examined. Tissues were fixed in $10 \%$ neutral buffered formalin for $24-48 \mathrm{~h}$, dehydrated, blocked in paraffin wax and sectioned at $5 \mu \mathrm{m}$. Egg albumin-glycerin adhesive was used to attach the sections on to clean glass slides. 


\section{METHOD}

The chromic acid or periodic acid-ammoniacal silver reaction to demonstrate mycobacteria and fungi in tissues is carried out as follows.

1 Deparaffinize sections in xylene and hydrate through graded alcohols to water.

2 (a) Oxidize in $5 \%$ chromic acid for $1 \mathrm{~h}$ followed by $2 \%$ sodium bisulphite briefly, or (b) oxidize in $1 \%$ periodic acid overnight.

3 Wash in running tap water, and rinse in 3 changes of distilled water.

4 Place sections in a Coplin jar containing freshly prepared ammoniacal silver solution, and place the jar in an oven at $60^{\circ} \mathrm{C}$ for about $1-2 \frac{1}{2} \mathrm{~h}$, until the sections turn brown to black (see below).

5 Rinse in 2 or 3 changes of distilled water at $60^{\circ} \mathrm{C}$, and then in several changes of distilled water at room temperature.

6 Tone in $0 \cdot 1 \%$ gold chloride for $5 \mathrm{~min}$.

7 Rinse in distilled water.

8 Fix in $2 \%$ sodium thiosulphite for $2 \mathrm{~min}$.

9 Wash in tap water.

10 Stain nuclei with nuclear-fast red solution for $15 \mathrm{~min}$.

11 Rinse in tap water.

12 Counterstain with $0 \cdot 01 \%$ methyl blue (Merck, art. 16316), or with $0 \cdot 03 \%$ methyl blue (Merck, art. 16315) in saturated aqueous picric acid solution for $5 \mathrm{~min}$.

13 Dehydrate directly in absolute alcohol.

14 Clear in terpineol-xylene $(1: 1)$, followed by xylene. Mount.

\section{AMMONIACAL SILVER SOLUTIONS}

Solutions are prepared in one of three ways.

1 Ammoniacal silver nitrate: to $25 \mathrm{ml}$ of $10 \%$ aqueous silver nitrate solution add $28 \%$ ammonia water until a clear solution is formed. Then add $10 \%$ silver nitrate drop by drop till a faint cloudiness appears. Add $25 \mathrm{ml}$ distilled water.

2 Ammoniacal silver carbonate: to $10 \mathrm{ml}$ of $10 \%$ aquaeous silver nitrate add $40 \mathrm{ml}$ of $5 \%$ anhydrous silver carbonate. When the precipitate has settled, remove the supernatant and wash the deposit several times with distilled water. Decant. Add $28 \%$ ammonia water drop by drop till the precipitate is dissolved. Add $10 \%$ aquaeous silver nitrate drop by drop till the solution becomes cloudy. Make up to $100 \mathrm{ml}$ with distilled water.

3 Ammoniacal silver hydroxide solution: to $10 \mathrm{ml}$ of $10 \%$ silver nitrate solution add $5 \mathrm{ml}$ of $4 \%$ $\mathrm{NaOH}$ till a black precipitate is formed. Add $28 \%$ ammonia drop by drop till the solution is cloudy. Make up to $100 \mathrm{ml}$ with distilled water.

\section{STAINING TIMES}

1 Ammoniacal silver nitrate:

2 Ammoniacal silver carbonate:

3 Ammoniacal silver hydroxide:
After chromic After periodic acid oxidation acid oxidation

$\begin{array}{ll}2 \mathrm{~h} & 2 \mathrm{~h} \\ 1 \mathrm{hr} 40 \mathrm{~min} & 2 \mathrm{~h} 45 \mathrm{~min} \\ 50 \mathrm{~min} & 1 \mathrm{~h} 10 \mathrm{~min}\end{array}$

NUCLEAR STAIN $1 \mathrm{~g}$ nuclear-fast red (CI 60760)

$5 \mathrm{~g}$ aluminium sulphate

$100 \mathrm{ml}$ distilled water. 


\section{Results}

Mycobacteria and fungi stain black, mucin brown-black, melanin grey, nuclei pink-red, and connective tissue green-grey-black. In pulmonary lesions carbon remains black (see Figures 1, 2 and $3)$.

\section{Discussion}

The method described for mycobacteria, including $M$. leprae and $M$. tuberculosis, and fungi in tissues is based on a chemical reaction which is both sensitive and reliable. The mechanism of the reaction depends on the oxidation of lipid hydroxy-amino groups in the mycobacterial cell wall and the release of free aldehydes. These aldehydes can be revealed either by a modified Schiff procedure using carbol-pararosanilin, ${ }^{3,4}$ or by treatment with silver salt solutions which are reduced to metallic silver. The present method utilizes ammoniacal silver salts rather than the methanamine used previously. ${ }^{9,10}$ Ammoniacal silver is used to demonstrate melanin. After oxidation melanin is only poorly recognizable but other substances like argentaffin, ascorbic acid, uric acid and polyphenols react with argyrophilic stains in a manner similar to aldehydes, and silver is deposited at the site of interaction. This in no way hinders the recognition of the mycobacteria or fungi, though carbon particles in the lung can sometimes mask bacilli in that tissue.

Chromic acid has the same oxidizing potential as periodic acid, but strict control of the oxidation time is necessary. Prolonged oxidation in chromic acid carries the risk of losing the aldehydes released, upon which the subsequent binding by carbol-pararosanilin, ${ }^{3,4}$ or impregnation

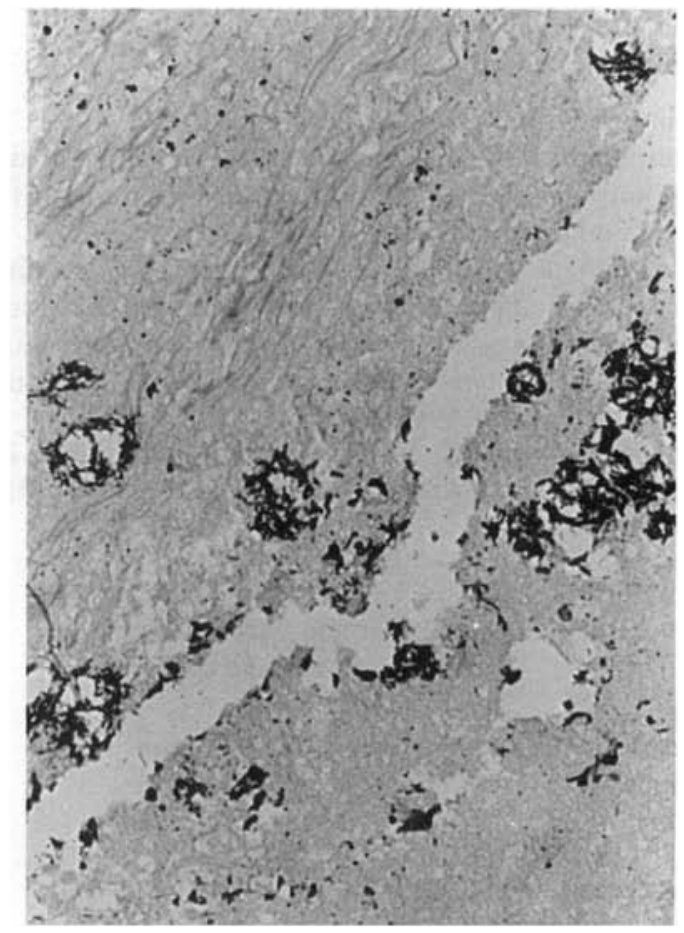

Figure 1. Tubercle bacilli in pulmonary tuberculosis. Periodic acid-ammoniacal silver hydroxide stain. 


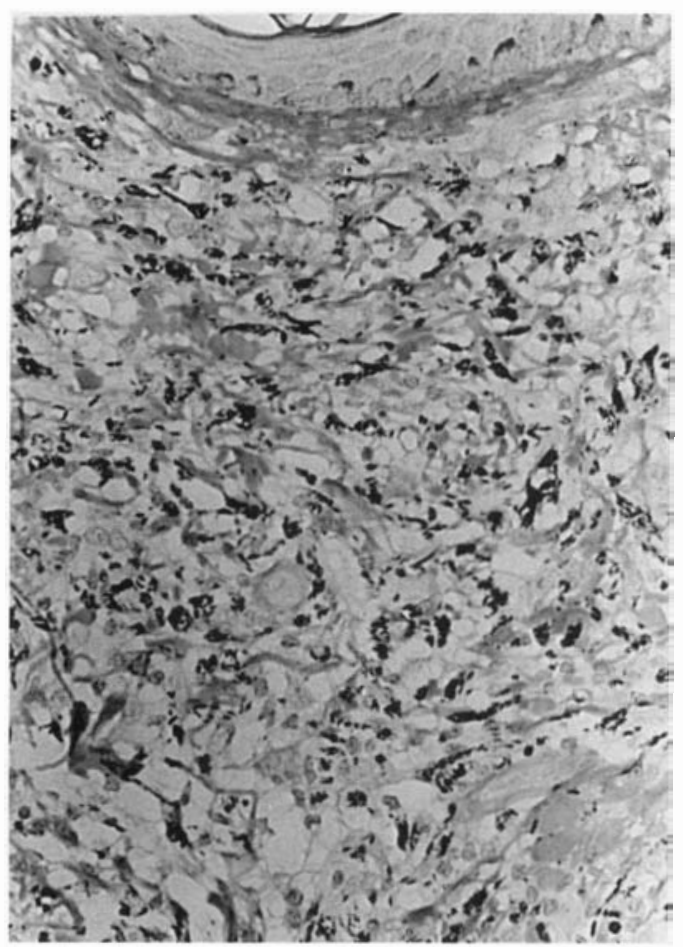

Figure 2. Leprosy bacilli in lepromatous lesion of skin. Periodic acid-ammoniacal silver hydroxide stain.

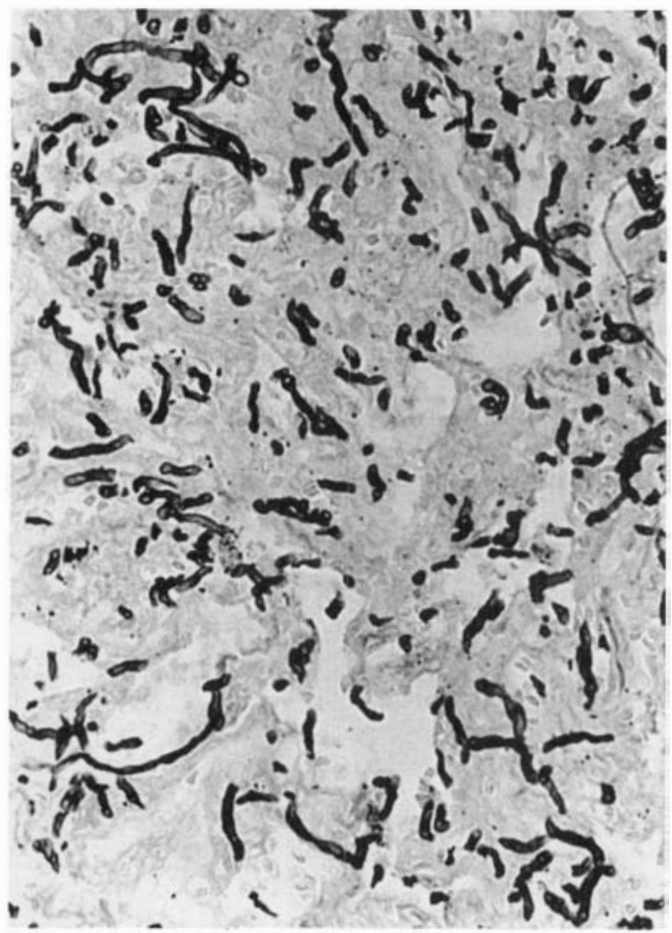

Figure 3. Fungi in pulmonary tuberculosis. Periodic acid-ammoniacal silver hydroxide stain. 
with silver depends. For this reason periodic acid is to be preferred in spite of the longer time required for the oxidation.

The majority of the $M$. leprae stained by the chromic or periodic acid-ammoniacal silver technique, stain with a uniform solid appearance. Even nonsolid bacilli appear rod-shaped. Thus the usefulness of the method does not extend to studies on viability or assessment of the bacteriological state of the patient. Nevertheless, its application in diagnosis and research cannot be emphasized too strongly. In research the ease of identifying organisms and degradation products, which are often difficult to detect by acid-fast staining, is comparable in many ways to the sensitivity of immunocytochemical methods using antiBCG antibody. Material stained by the two methods in parallel correlated very well (M J Ridley, personal communication 1988). The fact that granular and degraded bacilli stain with a solid appearance is understandable considering that it is the lipid moiety in the bacterial cell wall itself that is the key substance on which the reaction is effected. The disintegration of cell walls is achieved with difficulty in the case of $M$. leprae, especially so in lepromatous infections in which clearance of bacilli presents further problems.

\section{Acknowledgments}

The work was supported in part by a research grant from the Department of Health and Welfare of Japan, and the Arima Memorial Medical Foundation. Photography was done by Mr K Kawasu of the National Institute for Leprosy Research, Japan.

\section{References}

1 Nyka W. Method for staining both acid-fast and chromophobic tubercle bacilli with carbol fuchsin. $J$ Bact, 1967; 93: 1458-60.

2 Nyka W, O'Neill EF. A new approach to the study of non-acid-fast mycobacteria. Ann New York Acad Sci, 1970; 174: 862-71.

${ }^{3}$ Harada K. A modified allochrome procedure for demonstrating mycobacteria in tissue sections. Int J Lepr 1977; 45: 49-51.

4 Harada K. Staining mycobacteria with periodic acid-carbol pararosanilin: principles and practice of the method. Microscopia Acta, 1977; 79: 224-236.

5 Grocott RG. A stain for fungi in tissue sections and smears using Gomori methanamine silver nitrate technic. Amer J Pathol, 1955; 25: 975-79.

${ }^{6}$ Nyka W. Studies on Mycobacterium tuberculosis in lesions of the human lung. A new method of staining tubercle bacilli in tissue sections. Amer J Resp Dis, 1963; 88: 670-9.

7 Sutter E, Roulet FC. Staining Mycobacterium leprae in paraffin sections by Gomori methenamine silver method. Stain Technol, 1965; 40: 49-51.

8 Ridley MJ. The degradation of Mycobacterium leprae by a comparison of its staining properties. Int J Lepr, 1983; 51: 211-18.

9 Harada K. Periodic acid-methenamine silver stain for mycobacteria in tissue sections. Stain Technol, 1976; 51: $278-80$.

10 Harada K. An allochrome periodic acid methenamine silver stain for demonstrating mycobacteria. Jap $J$ Lepr, 1979; 171-5. 